\title{
Does Limitation Rule in International and Regional Human Rights Law Instruments Restrict Its Implementation?
}

\author{
Nurhidayatuloh, Febrian, Annalisa Y, Akhmad Idris, Rd Muhammad Ikhsan, Helena Primadianti \\ Sulistyaningrum, Fatimatuz Zuhro
}

\begin{abstract}
Provisions regarding limitation in human rights are contained inside international law instruments from UDHR, ECHR to ICCPR. Article 30 of UDHR, Article 17 of ECHR and Article 5(1) of ICCPR stipulate limitation rule, which is almost the same. When UDHR and ICCPR use both "limitation" and "restriction" with the same meaning, ECHR more consistent use restriction in its articles. However, there are several problems about why the rules of limitation are arranged in these written documents which are the critical foundation of universal human rights and justify fundamental freedom.

Moreover, those articles are then supplemented by provisions on public morals, which were allegedly a loophole for several states to restrict human rights in their jurisdiction. This qualitative research uses statute and historical approaches which discuss provisions regarding to limitation rule on several global and local human rights written documents as the derivation. Thus, analysis of those instruments and the travaux preparatoires are inevitable to make this article more challenging. The problems such as when the first time and why this concept is adjusted in those instruments will be the primary concern in this research. Furthermore, how the idea is implemented in regional human rights apparatuses, especially in the European Court of Human Rights will complement the discussion in this article.
\end{abstract}

Index Terms: Limitation Rule; Human Rights; UDHR; ECHR; ICCPR; (ECtHR)

\section{INTRODUCTION}

The provision regarding limitation is a crucial matter to discuss because of a limited number of materials explaining this concept. International human rights instruments use the main reference from Article 29 and 30 Universal Declaration of Human Rights (UDHR). This is also acknowledged by Bert B. Lockwood who argue that to find out what the meaning of limitation, it must be traced from the travaux preparatoires of the international instruments besides looking at the practices implemented in regional human rights systems, for example, the European Human

Revised Manuscript Received on September 22, 2019

Nurhidayatuloh, Faculty of Law, Universitas Sriwijaya., nurhidayatuloh@fh.unsri.ac.id

Febrian, Faculty of Law, Universitas Sriwijaya

Annalisa Y, Faculty of Law, Universitas Sriwijaya

Akhmad Idris, Faculty of Law, Universitas Sriwijaya

Rd Muhammad Ikhsan, Faculty of Law, Universitas Sriwijaya

Helena Primadianti S, Faculty of Law, Universitas Sriwijaya

Fatimatuz Zuhro, Faculty of Sharia and Law, Sunan Kalijaga State Islamic University
Rights Court and the UN Human Rights Committee (Bert B. Lockwood, 1985).

The declaration is essential to trigger a more binding follow-up treaty. As it happened in the Universal Declaration of Human Rights, which was then monitored up by the European Convention on Human Rights in 1950. It is considered as the first human rights instrument in the world which had binding characteristics and two international contracts on civil and political rights (Renshaw, 2013).

Provisions regarding limitation have been found in several declarations governing human rights. However, there are still some debates about why the rules of restriction enter into notifications that are very important and uphold human rights and fundamental freedoms. Moreover, the provisions governing public morals are alleged to be a gap for states to limit human rights.

It is noted that the UDHR and the ECHR, show remarkable similarities where the ECHR adopts the provisions regarding limitations from the UDHR directly. Afterwards, Article 17 of ECHR becomes the foundation for the European human rights mechanism in dealing with cases related to restriction in the ECtHR. Therefore, this research discusses the background of the emergence of limitation provisions in the UDHR, ECHR, and analyse the implementation of limitation provisions on provincial human rights mechanisms as in the European Human Moralities Court.

\section{LITERATURE REVIEW}

From the literature that the author explores, several articles have discussed limitation as to the main topic of discussion. However, on the other hand, some other writers also make the concept of limitation only as a sub-chapter of the scientific article. Just like the Amrei Muller article titled the Limitations and Derogations of Economic, Social and Cultural Rights, which discussed the differences and overlapping the idea of limitation and derogation in the ICESCR (Muller, 2009).

Hovius Berend (B Hovius - Yearbook of European Law, 1986) in his work entitled "discusses the concept of limitation by comparing the boundary to the ECHR and the Canadian Charter of Rights and Freedoms. He concluded that any restrictions in the ECHR must be determined through domestic law and the

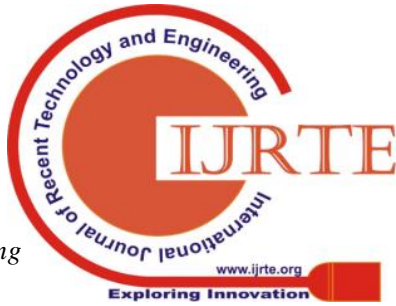


limitation must be definite. The clause on this limitation has provided a very flexible way to balance various interests. The ECHR and the Canadian Charter have also allowed the organ of the Convention to comply with the decisions of domestic authorities by making the convention protection in terms of restrictions that cannot be justified (Hovius, 1986).

None of the articles discussed by the legal scientists above have considered the addressed concept of limitation starting from the UDHR, ECHR to see what happened in the travaux preparatoires of the instrument so that it can be known what the purpose of the limitation is. Also, how this concept is implemented in the ECtHR will be a differentiator of this paper with other writings.

\section{METHODOLOGY/MATERIALS}

The approach used in this study is a normative approach (Soekanto, 2013) or doctrinal (Sunggono, 1997) to examine certain concepts in global and local human rights written documents. In this context, the idea that will be explored is the limitation concept contained in the UDHR, ECHR and practice in the ECtHR. The instrument was then analysed descriptively and analytically using qualitative data analysis and problem-solving (Widi, 2010).

\section{RESULTS AND FINDINGS}

When there is a question whether human rights emerge together with the acceptance of the UDHR by the UN General Assembly? This question leads to the existence of human rights itself. When the question is answered, yes, the consequence is that the UDHR has created new rights for human beings. But on the contrary, when the answer is, no, it can be implicitly concluded that human rights had existed before the UDHR was adopted and the UDHR only validated human rights that had existed in the form of values that lived in society for hundreds or even thousands of years.

This is supported by several statements from the leading figures composing the UDHR itself, namely, René Cassin (Schabas, 2013) and Count Carton de Wiart (Schabas, 2013) who consider that the human rights contained in the UDHR are moral values that are inherent in humans and are the beginning of fair values.

Although implicitly they state that the UDHR is not legally sufficient to be declared as a binding instrument, but the moral values contained are resulting of binding nature, and UDHR in the sense of codified values has been enshrined by the UN Charter and is a step of the beginning of legal costs. The thing that makes the UDHR is an extraordinary work because it provides certainty of protection for humans, but at the same time, it also imposes certain restrictions on mankind (Schabas, 2013).

\section{A. Limitation in the UDHR}

Provisions regarding limitations in UDHR are regulated in Article 29 and 30 UDHR. From this article, then similar rules appear on the ECHR and ICCPR. So it seems to me that when understanding this limitation, UDHR has the most significant role because either directly or indirectly, this regulation affects the limitation provisions that exist in human rights instruments afterwards.

The declaration stated that all rights contained in the UDHR constitute "a common standard of achievement for all peoples and all nations" where in the natural law perspective these rights have long been possessed by humans, and the UDHR only codifies those rights rather than creating new rights (Morsink, 1984). This means that this natural right has been inherent in humans and is not a gift from anyone. This is in line with the statement of Thomas Paine, which states that the origin of human rights can be traced in the process of creating the human itself (Morsink, 1984). So, this is wrong when the state seizes this right. The relationship between individuals and the nation about human rights is explained through social contract theory where the country, in this case, has obligations for protection, promulgation and implementation of human rights (Nurhidayatuloh et al., 2018) that have been inherent in humans themselves. Therefore, the state does not have the authority to eliminate these rights except to protect similar human rights (Morsink, 1984). With this basis, then the state has the power to regulate limitations on human rights to protect the rights and sovereignties of others.

The provisions regarding this limitation have been owned by several constitutions in several countries in Asia, America and Europe such as China, France, Paraguay and Turkey. These values were later adopted into the UDHR. In the Chinese Constitution, it is stated that rights and freedoms can be limited with primary reasons such as the rights and freedoms of others. France, Declaration of Rights of Man and of Citizens, 26 August 1789 also states that freedom can be limited by not harming others, and this limit of freedom can only be regulated through law. The Paraguay Constitution also says that democracy is social and can be limited by law. Similarly, the Turkish Constitution also states that freedom can be carried out as long as it does not harm other people, and this limit must be regulated in the law.These values in these countries were later adopted into the UDHR.

Panama also explicitly commented on the article stating that:

Some of these inputs were then included in the Draft Outline of the International Bill of Rights (prepared by the Division of Human Rights) which contains provisions regarding limitation in Article 2 "The exercise of his rights is limited by the State and the United Nations." However, there is some rejection regarding limitation provisions placed at the beginning of the UDHR. As Dr Malik from Lebanon stated that "It was odd that such limitations should be placed at the very beginning of a Bill...". It is explicitly stated that the limitation principle must be rigidly regulated as Mr Wilson from the United Kingdom noted that if the limitation provisions were not regulated in detail, it would position the country, in this case, the government, in a difficult situation. In the end, the article relating to this limitation is included in Article 29. Because the debate does not find an agreement, voting is needed for this

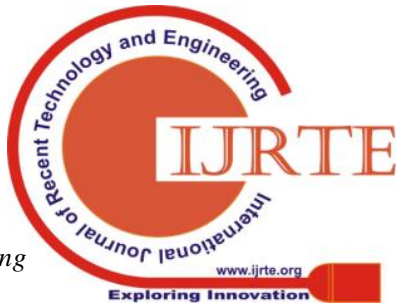


article. In this voting Article 29 was then adopted with 47 votes with eight abstentions.

Many opinions argue that the main character of the UDHR can be seen in Articles 4, 23 and 29. Article 4 proclaims the right of the individual to life, freedom and personal security; Article 23 stated that everyone was entitled to the economic, social and cultural rights indispensable for his dignity, and social security; Article 29 proclaimed the need for just social order and international orders - the two essential elements for the exercise of fundamental human rights. Likewise with René Cassin who stated that there are four pillars of UDHR, namely personal reasons, relationships between man and his fellow men, public liberties and fundamental political rights, and economic and social rights (Schabas, 2013). Also, he added that the final UDHR manuscript besides giving rights and freedom to individuals (Handayani, 2017) but also at the same time applying restrictions on human freedom.

\section{B. Limitation in the ECHR and ECtHR}

In addition to the ECHR, the ICCPR is also known as limitation and restriction. The word limitation and restriction can make confusion because of different interpretations. Nevertheless, basically in the process of making the covenant, the committee of experts suggested to distinguish the use of the two terms limitation and restriction, but in the implementation both in the covenant text and in the travaux preparatoires the use of the word limitation also included the word restriction (Kiss, 1985). As found in the travaux preparatoires that Article 5 (1) of the ICCPR is a derivative of article 30 UDHR whose purpose is to prevent misinterpretation of rights which can be carried out by limitation (Bert B. Lockwood, 1985).

As mentioned in the introductory chapter, the provisions concerning limitation in the ECHR are regulated in Article 17 of the ECHR which concludes the interpretation of actions that aim to destroy the rights and freedoms of individuals other than those stipulated in the limitation provisions. This is revealed in the ECHR's travaux preparatoires which say that the purpose of regulating Article 17 is to prevent adherents of totalitarian doctrine from exploiting the rights of the European Convention to destroy human rights (Bert B. Lockwood, 1985).

Disputes regarding this article took place on August 19, 1949, starting from the First session of the Consultative Assembly of the Council of Europe to subsequent meetings. The exciting debate was the statement of one of the representatives from France, M. Teitgen, who assumed that those who declared anti-communism with claims to eradicate communism but by dictator methods sometimes also jeopardized the principles of democracy. He also emphasized that the article on this limitation give the state the authority to limit freedom where public orders and security are threatened. However, even though the state has the power to make restrictions on the land, it must fulfil certain conditions for which the terms of the conditions have been determined in the ECHR. (Rights, 1957).

The articles concerning rights and freedoms that can be carried out a limitation in the ECHR are contained in Articles 8, 9, 10 and 11. In the section, there are three conditions that must be fulfilled, namely: or necessary in a democratic society (Hovius, 1986). About the terms " by the law" and "prescribed by law", the European Court of Human Rights has provided much jurisprudence regarding the meaning of the two terms. In the case of Barthold $\mathrm{v}$, the Federal Republic of Germany, ECtHR decided that the Convention organs should generally refer to the domestic authorities' interpretation and application of local domestic law. This right means that the national law of a country has an essential role in determining the limitation even though in its development State's domestic law must also have a good quality and following by the principles of the rule of law.

In addition to the limitation, provisions must be adjusted with national law, the state in conducting the limitation must also be carried out within the framework "necessary in a democratic society" for one of the prescribed purposes. These goals are also included in the article as an example in Article 8 ECHR where the limitation can be carried out with the aim of being limited to national security, public safety or the economic well-being of the country, for the prevention of disorder or crime, for the protection of health or morals, or protection of the rights and freedoms of others (Hovius, 1986).

Then the last condition is necessary for a democratic society. Appropriate words have different meanings with the word "indispensable" which is very strict also does not mean "admissible" which has soft meaning. This necessary word has the meaning "pressing social need" where the definition of ECtHR emphasizes the balance of the needs of society and the individual's right or freedom (Hovius, 1986).

In this case, it can be stated that the limitation provisions in the ECHR, as well as the training in the ECtHR, are intended to provide flexibility for the state to regulate restrictions on individual rights and freedoms where such restrictions are designed to harmonize existing relativism in the country.

\section{CONCLUSION}

There are two things that are of concern to this study, which is related to the first time, and reason concept of limitation is the UDHR and ECHR and the implementation of the limitation rule. After conducting research, it turned out that the idea of limitation was first universally regulated through the UDHR where the declaration then influenced several human rights instruments born later such as the ECHR and ICCPR. Although some of the designers of this declaration also considered that the UDHR was not binding, they agreed that this declaration was the beginning to trigger other human rights instruments that bind the state. This statement can also be found in the travaux preparatoires of the devices. Although the concept of limitation is universally regulated in the UDHR, basically this concept also takes from the limitation provisions that have been 
owned by countries in America, Europe and even Asia which have become their constitutions. So it can be concluded that the concept of limitation is not new in terms of the values that have been applied in the international community because these values have become the rule of law in the constitution in these countries.

Initially, the researcher considered that the provisions regarding this limitation contradicted the principle of universality of human rights, which in its implementation would limit the nature of the totality of human rights itself. However, after researching several

ECtHR decisions, it was found that in terms of its implementation the ECtHR in its jurisprudence gave authority to the state where it was permissible to limit a right according to their standards. However, in its implementation, there are three conditions that must be fulfilled by the state to restrict individual rights and sovereignties, namely, suggested by the law, have an acceptable target and in a democratic society.

\section{ACKNOWLEDGMENT}

This research work is supported by the Competitive Faeatured Research Project of 2019 sponsored by Universitas Sriwijaya.

\section{REFERENCES}

[1] Bert B. Lockwood, J., Janet Finn and Grace Jubinsky. (1985). Working Paper for the Committee of Experts on Limitation Provisions. Human Rights Quarterly, 7(1), 35-88.

[2] European Convention on Human Rights, (1950).

[3] Handayani, I. (2017). Responsibility to Protect: A New Form of Humanitarian Intervention? Padjadjaran Journal of International Law, 1(1), 51-67.

[4] Hovius, B. (1986). The Limitations Clauses of the European Convention on Human Rights and Freedoms and Section 1 of the Canadian Charter of Rights and Freedoms: A Comparative Analysis. Yearbook of European Law, 6(1), 1-54.

[5] Kiss, A. (1985). Commentary by the Rapporteur on the Limitation Provisions. Human Rights Quarterly, 7(1), 15-22.

[6] Morsink, J. (1984). The Philosophy of the Universal Declaration. Human Rights Quarterly, 6(3), 309-334.

[7] Muller, A. (2009). Limitations to and Derogations from Economic, Social and Cultural Rights. Human Rights Law Review, 9(4), 557-601.

[8] Nurhidayatuloh, N., Febrian, F., Romsan, A., Yahanan, A., Sardi, M., \& Zuhro, F. (2018). Forsaking Equality: Examine Indonesia's State Responsibility on Polygamy to the Marriage Rights In CEDAW. Jurnal Dinamika Hukum, 18(2), 182-193.

[9] Renshaw, C. S. (2013). The ASEAN Human Rights Declaration 2012. Human Rights Law Review, 13(3), 557-579. doi:10.1093/hrlr/ngt016

[10] Rights, S. o. t. E. C. o. H. (1957). Preparatory Work on Article 17 of the European Convention of Human Rights. Retrieved from https://www.echr.coe.int/LibraryDocs/Travaux/ECHRTravaux-ART17 -DH(57)4-BIL1675501.pdf

[11] Schabas, W. A. (2013). The Universal Declarataion of Human Rights The travaux préparatoires (Vol. 1). Cambridge: Cambridge University Press.

[12] Soekanto, S. (2013). Penelitian Hukum Normatif Jakarta: Rajawali Pers.

[13] Sunggono, B. (1997). Metode Peneitian Hukum. Jakarta: Rajawali Pers.

[14] Widi, R. K. (2010). Asas Metodologi Penelitian Sebuah Pengenalan dan Penuntunan Langkah Demi Langkah Pelaksanaan Penelitian Yogyakarta: Graha Ilmu. 